\title{
MODIFIKASI PANEL KONTROL SISTEM PENYEDIA AIR DINGIN PADA SISTEM VENTILASI ZONA RADIASI MENENGAH
}

\author{
${ }^{1}$ Paulus Sihombing, ${ }^{2}$ Nur Hanifah Yuninda, ${ }^{3}$ Massus Subekti \\ ${ }^{123}$ Pendidikan Teknik Elektro Fakultas Teknik, Universitas Negeri Jakarta \\ ${ }^{1}$ Email : paulussihombing51@gmail.com
}

\begin{abstract}
This research aims to design and make modifications to the control panel of cold water supply system in the ventilation system into the radiation zone semi-automatic medium so as to increase the value of the effectiveness and efficiency of the operation pattern 3 cold water supply system.

This study uses research and development and implemented in PRSG GAS BATAN, PUSPIPTEK SERPONG in november 2015 until June 2016. Modification of the control panel is used, CDAQ NI 9132, NI 9205, and 14.0 Labview software which will display chiller work in real time in graphs and nominal. Hardware input consists of, selector to choose the working water supply system cold, RTD PT100 as readers temperature of water entering the inlet pipe and the temperature of the water that comes out of the chiller, and sensor current transformer as a reader of electric current in the circulation pump, the output device is composed of pilot working as an indication lamp chiller and a thermostat to control the chiller via the inlet pipe. The steps to create the control panel modification of the draft, the control panel wiring, wiring input NI 9205, a program in Labview, then perform tests on the device.

Based on the results of testing known that the thermostat is able to control the chiller in accordance with the limits of the temperature setting on the thermostat. In the test results of pembacan incoming water temperature at the inlet pipe through the display labview program has a percentage error of $0.52 \%$, while data readings out of the water temperature chiller 1 has a percentage of the reading error of $0.57 \%$, the second chiller is $0,41 \%$ and chiller 3 is $0.45 \%$ and the data of electric current readings on the circulation pump shown in labview program has a percentage of error of $1.24 \%$ in chiller 1 , and $1.62 \%$ in the chiller 2 , and $1.27 \%$ the chiller 3 . Once the system has been tested as a whole, so that it can be concluded that the modification of the control panel of the cold water supply system can work properly according to the principles of work that has been made Keywords: Chiller Water system, Thermostat, LabVIEW, DAQ NI 9132, NI 9205, RTD PT100, Sensor Current Transformer.
\end{abstract}

\begin{abstract}
Abstrak
Sistem penyedia air dingin yang berjumlah 3 unit pada PRSG GAS BATAN sebagai penghasil air dingin memiliki pola pengoperasian secara manual yang kurang efektif dan efesisen sehingga kurang optimal.

Penelitian ini bertujuan untuk merancang dan membuat modifikasi panel kontrol sistem penyedia air dingin pada sistem ventilasi zona radiasi menengah menjadi semi otomatis sehingga dapat meningkatkan nilai efektifitas dan efesiensi dari pola pengoperasian 3 sistem penyedia air dingin.

Penelitian ini menggunakan metode penelitian dan pengembangan dan dilaksanakan di PRSG GAS BATAN, PUSPIPTEK SERPONG pada bulan november 2015 sampai juni 2016. Modifikasi panel kontrol ini menggunakan, CDAQ NI 9132, NI 9205, dan software Labview 14.0 yang akan menampilkan kerja chiller secara real time dalam bentuk grafik dan nominal. Peralatan input terdiri dari, selektor untuk memilih kerja sistem penyedia air dingin, RTD PT100 sebagai pembaca suhu air yang masuk pada pipa inlet dan suhu air yang keluar dari chiller, dan sensor current trafo sebagai pembaca listrik pada pompa sirkulasi, peralatan output terdiri dari pilot lamp sebagai indikasi kerja chiller dan thermostat untuk mengontrol chiller melalui pipa inlet. Langkah-langkah pembuatan modifikasi panel kontrol dari membuat rancangan, wiring panel kontrol, wiring input NI 9205, program pada Labview, kemudian melakukan uji coba pada alat.

Berdasarkan hasil dari pengujian diketahui bahwa thermostat mampu mengontrol chiller sesuai dengan batas setting suhu pada thermostat. Pada hasil pengujian dari pembacan suhu air yang masuk pada pipa inlet melalui tampilan program labview memiliki presentase kesalahan sebesar 0,52\%, sedangkan data hasil pembacaan suhu air keluar dari chiller 1 memiliki presentase kesalahan pembacaan sebesar 0,57\%, pada chiller 2 ialah $0,41 \%$ dan chiller 3 ialah $0,45 \%$ dan data hasil pembacaan listrik pada pompa sirkulasi yang ditampilkan dalam program labview memiliki presentase kesalahan $1,24 \%$ pada chiller 1 , dan 1,62\% pada chiller 2 , dan $1,27 \%$ pada chiller 3. Setelah sistem diuji secara keseluruhan, sehingga dapat disimpulkan bahwa modifikasi panel kontrol sistem penyedia air dingin dapat bekerja dengan baik sesuai prinsip kerja yang telah dibuat
\end{abstract}

Kata Kunci : Sistem Penyedia Air Dingin, Thermostat,.Labview, CDAQ NI 9132, NI 9205, RTD PT100, Sensor Trafo 


\section{PENDAHULUAN}

Sistem penyedia air dingin (chilled water system) merupakan sistem yang berfungsi sebagai alat pendingin air. Air dingin yang dihasilkan dari sistem penyedia air dingin atau chiller di alirkan melalui pipa outlet menuju AHU (Air Handling Unit) untuk digunakan sebagai pendingin pada sistem sirkulasi udara yang merupakan bagian dari sistem ventilasi zona radiasi menengah gedung RSG-GAS BATAN.

Sistem penyedia air dingin pada gedung RSGGAS BATAN zona radiasi menengah dilengkapi dengan tiga buah CWU (Chiller Water Unit) yang masing-masing mempunyai kapasitas sekitar 111,3 TR (Ton of Refrigeration).

Pola pengoperasian ketiga sistem penyedia air dingin atau chiller QKJ01/02/03 saat ini dilakukan dengan cara manual menggunakan panel kontrol lama yang berada di ruang bawah gedung reaktor pada tekanan $-6,5$ bar, dimana pada proses menghidupkan ketiga chiller tidak di kontrol secara otomatis sesuai dengan perubahan suhu air yang masuk pada pipa inlet, melainkan dengan cara menggunakan 3 push button pada panel kontrol pada masing-masing chiller.

Salah satu prosesnya dalam menghidupkan ketiga chiller ialah ketika suhu air yang masuk pada pipa inlet mengalamai suatu kenaikan suhu pada skala $12^{\circ} \mathrm{C}$ dengan melakukan pengcekan berkala pada pipa inlet, maka seorang teknisi $\mathrm{h}$ turun ke ruang bawah gedung reaktor pada tekanan -6,5 bar untuk menghidupkan 2 chiller dari 3 chiller secara manual dengan push button.

Setiap perubahan suhu air yang masuk pipa inlet mengalami suatu kenaikan ataupun penurun suhu air yang masuk, maka seorang teknisi h selalu melakukan pengecekan pada pipa inlet dan turun ke bawah gedung reaktor pada tekanan $-6,5$ bar untuk menghidupkan atau mematikan chiller menggunakan push button secara manual pada panel kontrol lama, melalui cara ini dampak yang terjadi pada pengoperasian chiller yang dilakukan secara manual akan mengurangi tingkat efektifitas dan efesiensi chiller.

Untuk itu peneliti melalukan suatu penelitian terkait sistem pengoperasian chiller yang berjumlah 3 unit pada RSG GAS BATAN, fokus peneliti pada penelitian ini ialah memodifikasi sebuah panel kontrol chiller untuk meningkatkan kerja chiller supaya lebih efektif dan efesien dalam pola pengoperasinya sehingga menghemat energi dalam proses menghidupkan chiller.

\section{METODE}

\section{Tempat dan Waktu Penelitian}

Tempat penelitian adalah di PRSG-GAS BATAN. Penelitian dilakukan pada bulan November 2015-Juli 2016.

\section{Metode Penelitian}

Metode yang digunakan dalam melakukan penelitian ini adalah metode penelitian dan pengembangan yaitu dengan cara merancang, membuat dan uji fungsi modifikasi panel kontrol sistem penyedia air dingin pada system ventilasi zona radiasi menengah PRSG GAS BATAN

\section{Teknik Analisi Data}

Analisis data yang peneliti lakukan secara deskriptif, yaitu mendeskripsikan atau menjelaskan hasil uji pada thermostat dalam mengontrol chiller 1 , chiller 2 , dan chiller 3 sesuai dengan perubahan suhu air pada pipa inlet, dan analisis data hasil pengujian pada sensor RTD PT100 dan sensor current trafo dibandingkan dengan termometer dan tang ampere, analisis data dilakukan secara runut dan detail yang dilengkapi dengan tabel hasil pengujian, selanjutnya dicari nilai selisih dan prosenatase kesalahan dari sensor RTD PT100 dan current trafo

\section{HASIL DAN PEMBAHASAN Deskripsi Hasil}

Sistem penyedia air dingin yang berada di Pusat Reaktor Serba Guna GAS BATAN berjumlah 3 unit diberi kode QKJ 01 (chiller 1), QKJ 02 (chiller 2), dan QKJ 03 (chiller 3). Masing-masing unit sistem penyedia air dingin atau chiller memiliki kapasitas pendingin sebesar 111,33 TR (Ton of Refrigeration), dalam proses menghidupkan sistem penyedia air dingin atau chiller, sebagai media pendingin, sebelumnya masih menggunakan prinsip manual dengan cara menghidupkan masing-masing chiller menggunakan push button pada panel kontrol yang berada di tekanan -6,5 didalam gedung reaktor sehingga kurang optimal dengan menghabiskan waktu yang lama dalam pola pengoperasiannya, jadi kurang efesien dan kurang efektif.

Sehingga peneliti melakukan modifikasi panel kontrol sistem penyedia air dingin menjadi sistem 
semi otomatis sebagai salah satu upaya untuk meningkatkan kinerja suatu sistem penyedia air dingin menjadi lebih efesien dan efektif, yaitu dengan mengontrol sistem penyedia air dingin atau chiller 01/02/03 menggunakan thermostat multistage yang di pasang pada pipa inlet menuju chiller dengan memiliki 2 kontak SPDT didalamnya, masing masing keluaran dari kontak normaly Open SPDT dihubungkan pada 2 kontak NO (Normaly Open) kontaktor tipe 3NO,1NC

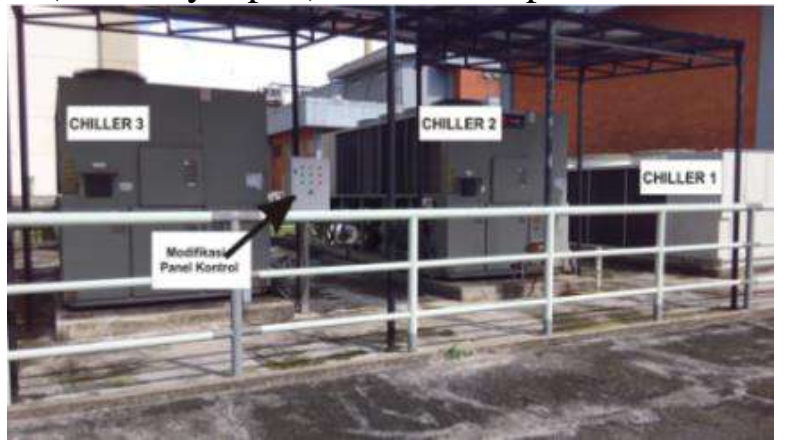

Gambar 1. Modifikasi Panel Kontrol Sistem Penyedia

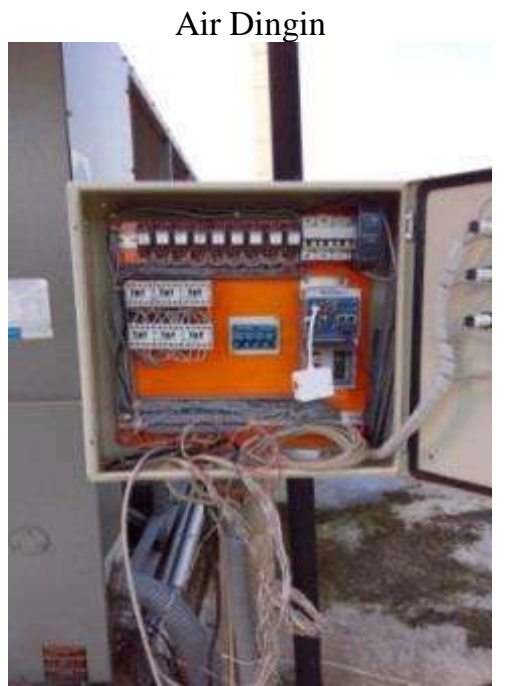

Gambar 2. Modifikasi Panel Kontrol Sistem Penyedia Air Dingin

\section{Pengujian Sensor RTD PT100 pada Pipa Inlet dan Pipa Outlet}

Hasil pengujian hardware ini merupakan hasil dari pengujian pada sensor RTD PT100 yang terhubung dengan terminal input signal conditioning, untuk membaca besaran nilai tegangan pada terminal output signal conditioning saat kondisi suhu air yang masuk pada pipa inlet dan suhu air yang keluar dari chillerl, chiller2, dan chiller 3 pada pipa outlet terdeteksi oleh RTD PT100 mengalami suatu perubahaan suhu. Pengujian ini dilakukan dengan mengukur tegangan keluaran pada terminal output signal conditioning.
Tabel. 1 Hasil Pengujian Tegangan pada RTD PT100 di Pipa Inlet

\begin{tabular}{|c|c|c|c|}
\hline $\begin{array}{l}\text { Suhu Air } \\
\text { Masuk } \\
\text { (Inlet) } \\
\left({ }^{\circ} \mathrm{C}\right) \mathrm{T}_{\mathrm{P}}\end{array}$ & $\begin{array}{c}\text { Tegangan } \\
\text { Output } \\
\text { (VDC) } \\
\text { V2 pipa inlet }\end{array}$ & 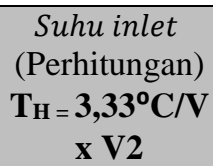 & $\begin{array}{c}\text { Error }_{\mathrm{T}} \\
\left(\frac{\Delta \boldsymbol{T}}{\boldsymbol{T}_{H}} \boldsymbol{x} \mathbf{1 0 0} \%\right)\end{array}$ \\
\hline $11.4^{\circ} \mathrm{C}$ & 3.42 & $11.38^{\circ} \mathrm{C}$ & 0.17 \\
\hline $12.0^{\circ} \mathrm{C}$ & 3.6 & $11.98^{\circ} \mathrm{C}$ & 0.16 \\
\hline $12.5^{\circ} \mathrm{C}$ & 3.75 & $12.48^{\circ} \mathrm{C}$ & 0.16 \\
\hline $13.5^{\circ} \mathrm{C}$ & 4.05 & $13.48^{\circ} \mathrm{C}$ & 0.14 \\
\hline $12.1^{\circ} \mathrm{C}$ & 3.63 & $12.08^{\circ} \mathrm{C}$ & 0.16 \\
\hline
\end{tabular}

Tabel. 2 Hasil Pengujian Tegangan pada RTD PT100 di Pipa Outlet Chiller 1

\begin{tabular}{|c|c|c|c|}
\hline $\begin{array}{l}\text { Suhu Air } \\
\text { keluar } \\
\text { chiller } 1 \\
\left({ }^{\circ} \mathrm{C}\right) T_{P}\end{array}$ & $\begin{array}{c}\text { Tegangan } \\
\text { Output ( } \\
\text { VDC) V2 pipa } \\
\text { outlet } 1\end{array}$ & 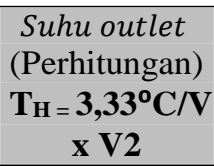 & $\begin{array}{c}\text { Error }_{\mathrm{T}} \\
\left(\frac{\Delta \boldsymbol{T}}{\boldsymbol{T}_{\boldsymbol{H}}} \boldsymbol{x} \mathbf{1 0 0} \%\right.\end{array}$ \\
\hline $8.2^{\circ} \mathrm{C}$ & 2.46 & $8.19^{\circ} \mathrm{C}$ & 0.12 \\
\hline $8.0^{\circ} \mathrm{C}$ & 2.40 & $7.99^{\circ} \mathrm{C}$ & 0.12 \\
\hline $7.7^{\circ} \mathrm{C}$ & 2.31 & $7.69^{\circ} \mathrm{C}$ & 0.13 \\
\hline $7.0^{\circ} \mathrm{C}$ & 2.10 & $6.99^{\circ} \mathrm{C}$ & 0.14 \\
\hline $7.5^{\circ} \mathrm{C}$ & 2.25 & $7.49^{\circ} \mathrm{C}$ & 0.13 \\
\hline
\end{tabular}

Tabel 3. Hasil Pengujian Tegangan pada RTD PT100 di Pipa Outlet Chiller 2

\begin{tabular}{|c|c|c|c|}
\hline $\begin{array}{l}\text { Suhu Air } \\
\text { keluar } \\
\text { chiller } 2 \\
\left({ }^{\circ} \mathrm{C}\right) T_{P}\end{array}$ & $\begin{array}{c}\text { Tegangan } \\
\text { Output ( } \\
\text { VDC) V2 } \\
\text { pipa outlet } 2\end{array}$ & 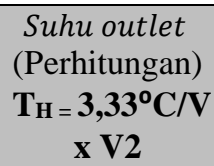 & $\begin{array}{c}\text { Error }_{\mathrm{T}} \\
\left(\frac{\Delta \boldsymbol{T}}{\boldsymbol{T}_{\boldsymbol{H}}} \boldsymbol{x} \mathbf{1 0 0} \%\right)\end{array}$ \\
\hline $7.0^{\circ} \mathrm{C}$ & 2.1 & $6.99^{\circ} \mathrm{C}$ & 0.14 \\
\hline $6.8^{\circ} \mathrm{C}$ & 2.04 & $6.79^{\circ} \mathrm{C}$ & 0.14 \\
\hline $6.30^{\circ} \mathrm{C}$ & 1.89 & $6.29^{\circ} \mathrm{C}$ & 0.15 \\
\hline $6.50^{\circ} \mathrm{C}$ & 1.95 & $6.49^{\circ} \mathrm{C}$ & 0.15 \\
\hline $6.40^{\circ} \mathrm{C}$ & 1.92 & $6.39^{\circ} \mathrm{C}$ & 0.15 \\
\hline
\end{tabular}

Tabel 4. Hasil Pengujian Tegangan pada RTD PT100 di

\begin{tabular}{|c|c|c|c|}
\hline \multicolumn{4}{|c|}{ Pipa Outlet Chiller 3} \\
\hline $\begin{array}{l}\text { Suhu Air } \\
\text { keluar } \\
\text { chiller } 3 \\
\left({ }^{\circ} \mathrm{C}\right) T_{P} \\
\end{array}$ & $\begin{array}{c}\text { Tegangan } \\
\text { Output ( } \\
\text { VDC) V2 } \\
\text { pipa outlet } 3 \\
\end{array}$ & 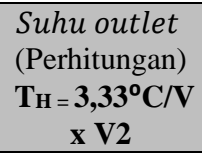 & $\begin{array}{c}\text { ErrorT } \\
\left(\frac{\Delta T}{T_{H}} x \mathbf{1 0 0} \%\right)\end{array}$ \\
\hline $8.14^{\circ} \mathrm{C}$ & 2.44 & $8.12^{\circ} \mathrm{C}$ & 0.24 \\
\hline $7.82^{\circ} \mathrm{C}$ & 2.34 & $7.79^{\circ} \mathrm{C}$ & 0.38 \\
\hline $7.64^{\circ} \mathrm{C}$ & 2.29 & $7.62^{\circ} \mathrm{C}$ & 0.26 \\
\hline $8.0^{\circ} \mathrm{C}$ & 2.40 & $7.99^{\circ} \mathrm{C}$ & 0.12 \\
\hline $7.80^{\circ} \mathrm{C}$ & 2.34 & $7.79^{\circ} \mathrm{C}$ & 0.12 \\
\hline
\end{tabular}

\section{Pengujian Thermostat pada Sistem Penyedia Air Dingin (Chiller)}

Pengujian ini dilakukan untuk mengetahui berapa besar tingkat efektifitas thermostat dalam membaca suhu air yang masuk pada pipa inlet dan mengontrol suhu air yang masuk pada pipa Inlet untuk menghidupkan chiller1, chiller 2, dan chiller 3 yang telah di setting pada skala suhu $11,5^{\circ} \mathrm{C}$. 
Tabel 5. Pengujian Thermostat pada Sistem Penyedia Air

\begin{tabular}{|c|c|c|c|c|c|}
\hline \multirow[b]{3}{*}{$\begin{array}{c}\text { Klasifikasi } \\
\text { Suhu }\end{array}$} & \multirow{3}{*}{$\begin{array}{l}\text { Mode } \\
\text { Basic } \\
\text { Chiller }\end{array}$} & \multicolumn{4}{|l|}{ Dingin } \\
\hline & & \multirow{2}{*}{$\begin{array}{c}\text { Hasil } \\
\text { aktual } \\
\text { Pengukuran } \\
\text { Suhu } \\
\end{array}$} & \multicolumn{3}{|c|}{ Kondisi Chiller } \\
\hline & & & $\begin{array}{c}\text { Chiller } \\
1\end{array}$ & $\begin{array}{c}\text { Chiller } \\
2\end{array}$ & $\begin{array}{c}\text { Chiller } \\
3\end{array}$ \\
\hline \multirow{2}{*}{$\geq 13,5^{\circ} \mathrm{C}$} & \multirow{4}{*}{$\begin{array}{c}\text { Chiller } \\
1\end{array}$} & $17,2 \circ \mathrm{C}$ & $\mathbf{O N}$ & $\mathbf{O N}$ & $\mathbf{O N}$ \\
\hline & & $13,6^{\circ} \mathrm{C}$ & ON & ON & ON \\
\hline $\begin{array}{l}13,5^{\circ} \mathrm{C}>\mathrm{x} \\
\geq 11,5^{\circ} \mathrm{C}\end{array}$ & & $11,6{ }^{\circ} \mathrm{C}$ & ON & ON & OFF \\
\hline$<11,5^{\circ} \mathrm{C}$ & & $\begin{array}{c}10,1{ }^{\circ} \mathrm{C} \\
5,7{ }^{\circ} \mathrm{C}\end{array}$ & $\begin{array}{l}\text { ON } \\
\text { ON }\end{array}$ & $\begin{array}{l}\text { OFF } \\
\text { OFF }\end{array}$ & $\begin{array}{l}\text { OFF } \\
\text { OFF }\end{array}$ \\
\hline$\geq 13,5^{\circ} \mathrm{C}$ & \multirow{3}{*}{$\begin{array}{c}\text { Chiller } \\
2\end{array}$} & $\begin{array}{l}16,1{ }^{\circ} \mathrm{C} \\
13,6{ }^{\circ} \mathrm{C}\end{array}$ & $\begin{array}{l}\text { ON } \\
\text { ON }\end{array}$ & $\begin{array}{l}\text { ON } \\
\text { ON }\end{array}$ & $\begin{array}{l}\text { ON } \\
\text { ON }\end{array}$ \\
\hline $\begin{array}{c}13,5^{\circ} \mathrm{C}>\mathrm{x} \\
\geq 11,5^{\circ} \mathrm{C}\end{array}$ & & $11.7{ }^{\circ} \mathrm{C}$ & OFF & ON & ON \\
\hline$<11,5^{\circ} \mathrm{C}$ & & $\begin{array}{l}9,9{ }^{\circ} \mathrm{C} \\
5,6{ }^{\circ} \mathrm{C}\end{array}$ & $\begin{array}{c}\text { OFF } \\
\text { ON }\end{array}$ & $\begin{array}{l}\text { ON } \\
\text { OFF }\end{array}$ & $\begin{array}{l}\text { ON } \\
\text { OFF }\end{array}$ \\
\hline$\geq 13,5^{\circ} \mathrm{C}$ & \multirow{3}{*}{$\begin{array}{c}\text { Chiller } \\
3\end{array}$} & $\begin{array}{l}18,1{ }^{\circ} \mathrm{C} \\
13,6{ }^{\circ} \mathrm{C}\end{array}$ & $\begin{array}{l}\text { ON } \\
\text { ON }\end{array}$ & $\begin{array}{l}\text { ON } \\
\text { ON }\end{array}$ & $\begin{array}{l}\text { ON } \\
\text { ON }\end{array}$ \\
\hline $\begin{array}{c}13,5^{\circ} \mathrm{C}>\mathrm{x} \\
\geq 11,5^{\circ} \mathrm{C}\end{array}$ & & $11,7 \circ \mathrm{C}$ & ON & OFF & ON \\
\hline$<11,5^{\circ} \mathrm{C}$ & & $\begin{array}{l}9,7 \circ \mathrm{C} \\
5,9 \circ \mathrm{C} \\
\end{array}$ & $\begin{array}{l}\text { OFF } \\
\text { OFF }\end{array}$ & $\begin{array}{l}\text { OFF } \\
\text { OFF }\end{array}$ & $\begin{array}{l}\text { ON } \\
\text { ON }\end{array}$ \\
\hline
\end{tabular}

\section{Pengujian Listrik pada Pompa Sirkulasi melalui LabVIEW}

Pengujian pembacaan nilai listrik pada pompa sirkulasi melalui software program Labview ditujukan menampilkan data hasil pembacaan besaran nilai listrik dari sensor current trafo secara real time mendekati hasil data yang diukur menggunakan tang ampere pada terminal sensor current trafo.

Tabel 6.Pengujian Monitoring Nilai Listrik Pompa Sirkulasi Pada Program Labview

\begin{tabular}{|c|c|c|c|}
\hline \multirow{2}{*}{ Waktu } & \multicolumn{3}{|c|}{$\begin{array}{c}\text { Chiller } 1 \\
\text { Pompa Sirkulasi (Ampere) }\end{array}$} \\
\hline & $\begin{array}{l}\text { LabView } \\
\text { (IL1) }\end{array}$ & $\begin{array}{l}\text { Tang Amp } \\
\text { (IT1) }\end{array}$ & $\varepsilon_{I}\left(\frac{\Delta I 1}{I T 1} x 100 \%\right)$ \\
\hline 12:00:00 & 9.55 & 9,5 & 0.52 \\
\hline $12: 30: 44$ & 9,60 & 9,5 & 1.05 \\
\hline 13:01:01 & 9,29 & 9,3 & 0.10 \\
\hline $13: 29: 09$ & 9,56 & 9,3 & 2.79 \\
\hline $14: 00: 42$ & 9,36 & 9,3 & 0.64 \\
\hline $14: 35: 37$ & 9,33 & 9,1 & 2.41 \\
\hline $15: 10: 42$ & 9,30 & 9,4 & 1.06 \\
\hline $15: 36: 11$ & 9,69 & 9,6 & 0.93 \\
\hline $16: 01: 45$ & 9,11 & 9.3 & 2.04 \\
\hline $16: 10: 30$ & 9,12 & 9,2 & 0.86 \\
\hline
\end{tabular}

\begin{tabular}{cccc}
\hline & \multicolumn{3}{c}{ Chiller 2 } \\
\cline { 2 - 4 } Waktu & \multicolumn{3}{c}{ Pompa Sirkulasi (Ampere) } \\
\cline { 2 - 4 } & $\begin{array}{c}\text { LabView } \\
\text { (IL2) }\end{array}$ & $\begin{array}{c}\text { Tang Amp } \\
\text { (IT2) }\end{array}$ & $\varepsilon_{2}\left(\frac{\Delta I 2}{I T 2} \times 100 \%\right)$ \\
\hline 12:00:00 & 9,31 & 9,3 & 0.10 \\
12:30:44 & 9,47 & 9,3 & 1.82 \\
13:01:01 & 9,39 & 9,3 & 0.96 \\
13:29:09 & 9,40 & 9,2 & 2.17 \\
14:00:42 & 9,41 & 9,3 & 1.18 \\
14:35:37 & 9,61 & 9,4 & 2.23 \\
15:10:42 & 9,46 & 9,3 & 1.72 \\
15:36:11 & 9,32 & 9,2 & 1.30 \\
$16: 01: 45$ & 9,56 & 9,3 & 2.79 \\
$16: 10: 30$ & 9,48 & 9,3 & 1.93 \\
\hline
\end{tabular}

\begin{tabular}{lccc} 
& \multicolumn{3}{c}{ Chiller 3 } \\
\cline { 2 - 4 } Waktu & \multicolumn{3}{c}{ Pompa Sirkulasi (Ampere) } \\
\cline { 2 - 4 } & $\begin{array}{c}\text { LabView } \\
\text { (IL3) }\end{array}$ & $\begin{array}{c}\text { Tang Amp } \\
\text { (IT3) }\end{array}$ & $\varepsilon_{I}\left(\frac{\Delta I 3}{I T 3} x 100 \%\right)$ \\
\hline 12:00:00 & 9,12 & 9,3 & 1.93 \\
12:30:44 & 9,20 & 9,3 & 1.07 \\
13:01:01 & 9,47 & 9,3 & 1.82 \\
13:29:09 & 9,11 & 9,2 & 0.97 \\
14:00:42 & 9,39 & 9,3 & 0.96 \\
14:35:37 & 9,24 & 9,2 & 0.43 \\
15:10:42 & 9,41 & 9,3 & 1.18 \\
15:36:11 & 9,53 & 9,6 & 0.72 \\
16:01:45 & 9,62 & 9,4 & 2.34 \\
16:10:30 & 9,42 & 9,3 & 1.29 \\
& \multicolumn{3}{c}{} \\
\hline
\end{tabular}

\section{Pengujian Monitoring Suhu Air pada Chiller} ( Pipa Inlet dan Pipa Outlet ) melalui Program Labview

Pengujian monitoring suhu air yang masuk pada pipa inlet dan suhu air keluar pada pipa outlet pada masing-masing chiller 1 , chiller 2 , dan chiller 3, bertujuan untuk mengetahui bagaimana program labview dapat menampilkan hasil pembacaan suhu oleh RTD PT100 berupa data nominal dan grafik pada chiller 1, chiller 2, dan chiller 3, dan menampilkan kondisi dari chiller saat dalam kondisi ON atau OFF, berdasarkan perubahan suhu air masuk pada pipa inlet yang terbaca oleh RTD PT100 dan di tampilan melalui Labview. Untuk dapat menampilkan kondisi chiller dan menampikan data hasil pembacaan oleh RTD PT100 pada program labview dalam front panel, dilakukan pemograman pada blok diagram menggunakan bahasa $\mathrm{G}$ (graphic)

Tabel 7. Pengujian Monitoring Pengukuran Suhu Air Masuk Pipa Inlet Dan Suhu Air Keluar Pipa Outlet Melalui Program Labview

\begin{tabular}{cccc}
\hline & \multicolumn{3}{c}{ Suhu Air Keluar Chiller $1\left({ }^{0} \mathrm{C}\right)$} \\
\cline { 2 - 4 } Waktu & $\begin{array}{c}\text { Lab VI } \\
\text { (Ts1) }\end{array}$ & $\begin{array}{c}\text { Termometer } \\
(\mathrm{Tt} 1)\end{array}$ & $\begin{array}{c}\boldsymbol{\varepsilon}_{t 1} \text { Error } \\
\left.\frac{\Delta \boldsymbol{T}}{\boldsymbol{T}_{\boldsymbol{t}} \mathbf{1}} \boldsymbol{x} \mathbf{1 0 0} \%\right)\end{array}$ \\
\hline 12:11:58 & 6.55 & 6.60 & 0.7 \\
12:37:00 & 6.56 & 6.64 & 1.2 \\
12:48:05 & 6.67 & 6.70 & 0.4 \\
13:06:49 & 6.69 & 6.76 & 1.03 \\
13:10:53 & 6.74 & 6.80 & 0.8 \\
13:50:40 & 6.79 & 6.82 & 0.3 \\
14:03:16 & 6.87 & 6.84 & 0.4 \\
14:10:06 & 6.89 & 6.90 & 0.1 \\
14:54:03 & 7.05 & 7.10 & 0.7 \\
15:04:03 & 7.20 & 7.20 & 0. \\
15:11:43 & 7.33 & 7.40 & 0.9 \\
15:50:22 & 7.68 & 7.60 & 1.05 \\
16:04:30 & 7.81 & 7.82 & 0.1 \\
16:10:41 & 7.87 & 7.90 & 0.3 \\
& $\% \mathcal{E}_{\boldsymbol{T}}$ & & $0.57 \%$ \\
\hline
\end{tabular}




\begin{tabular}{cccc}
\hline \multirow{2}{*}{ Waktu } & \multicolumn{3}{c}{ Suhu Air Keluar Chiller $2\left({ }^{0} \mathrm{C}\right)$} \\
\cline { 2 - 4 } & $\begin{array}{c}\text { Lab VI } \\
(\mathrm{Ts} 2)\end{array}$ & $\begin{array}{c}\text { Termometer } \\
(\mathrm{Tt} 2)\end{array}$ & $\begin{array}{c}\boldsymbol{\varepsilon}_{t 1} \text { Error } \\
\left.\frac{\Delta \boldsymbol{T}}{\boldsymbol{T}^{2}} \boldsymbol{x} \mathbf{1 0 0} \%\right)\end{array}$ \\
\hline 12:11:58 & 6.41 & 6.44 & 0.4 \\
12:37:00 & 6.42 & 6.46 & 0.6 \\
12:48:05 & 6.54 & 6.52 & 0.3 \\
13:06:49 & 6.66 & 6.60 & 0.9 \\
13:10:53 & 6.55 & 6.50 & 0.7 \\
13:50:40 & 6.53 & 6.54 & 0.1 \\
14:03:16 & 6.53 & 6.58 & 0.7 \\
14:10:06 & 6.60 & 6.62 & 0.3 \\
\hline
\end{tabular}

\begin{tabular}{|c|c|c|c|}
\hline \multirow[b]{2}{*}{ Waktu } & \multicolumn{3}{|c|}{ Suhu Air Keluar Chiller $2\left({ }^{\circ} \mathrm{C}\right)$} \\
\hline & $\begin{array}{l}\text { Lab VI } \\
\text { (Ts2) }\end{array}$ & $\begin{array}{l}\text { Termometer } \\
(\mathrm{Tt} 2)\end{array}$ & $\begin{array}{c}\varepsilon_{t 1} \text { Error } \\
\left.\frac{\Delta T}{T_{t} 2} x 100 \%\right)\end{array}$ \\
\hline $14: 54: 03$ & 6.66 & 6.66 & 0 \\
\hline $15: 04: 03$ & 6.79 & 6.74 & 0.7 \\
\hline $15: 11: 43$ & 6.80 & 6.86 & 0.8 \\
\hline $15: 50: 22$ & 6.91 & 6.90 & 0.1 \\
\hline $16: 04: 30$ & 6.93 & 6.92 & 0.1 \\
\hline $16: 10: 41$ & 6.95 & 6.94 & 0.1 \\
\hline & $\% \mathcal{E}_{T}$ & & $0.41 \%$ \\
\hline
\end{tabular}

\begin{tabular}{cccc}
\hline \multirow{2}{*}{ Waktu } & \multicolumn{3}{c}{ Suhu Air Keluar Chiller $3\left({ }^{0} \mathrm{C}\right)$} \\
\cline { 2 - 4 } & $\begin{array}{c}\text { Lab VI } \\
(\mathrm{Ts} 3)\end{array}$ & $\begin{array}{c}\text { Termometer } \\
(\mathrm{Tt} 3)\end{array}$ & $\begin{array}{c}\boldsymbol{\varepsilon}_{t} 3 \text { Error } \\
\left.\frac{\Delta \boldsymbol{T}}{\boldsymbol{T}_{t} \mathbf{3}} \boldsymbol{x} \mathbf{1 0 0} \%\right)\end{array}$ \\
\hline 12:11:58 & 6.51 & 6.50 & 0.1 \\
$12: 37: 00$ & 6.55 & 6.56 & 0.1 \\
$12: 48: 05$ & 6.67 & 6.60 & 1.06 \\
$13: 06: 49$ & 6.63 & 6.64 & 0.1 \\
$13: 10: 53$ & 6.62 & 6.68 & 0.8 \\
$13: 50: 40$ & 6.70 & 6.70 & 0. \\
14:03:16 & 6.73 & 6.74 & 0.1 \\
\hline
\end{tabular}

\begin{tabular}{cccc}
\hline Waktu & $\begin{array}{c}\text { Suhu Air } \\
\text { Keluar } \\
\text { Chiller } \\
1\left({ }^{\circ} \mathrm{C}\right)\end{array}$ & Waktu & $\begin{array}{c}\text { Suhu Air } \\
\text { Keluar Chiller } \\
1\left({ }^{0} \mathrm{C}\right)\end{array}$ \\
\hline 14:10:06 & 6.79 & 6.80 & 0.7 \\
$14: 54: 03$ & 6.85 & 6.88 & 0.4 \\
$15: 04: 03$ & 6.91 & 6.94 & 0.4 \\
$15: 11: 43$ & 6.95 & 7.0 & 0.7 \\
$15: 50: 22$ & 7.15 & 7.20 & 0.6 \\
$16: 04: 30$ & 7.27 & 7.28 & 0.9 \\
$16: 10: 41$ & 7.37 & 7.34 & 0.4 \\
& $\% \mathcal{E}_{\boldsymbol{T}}$ & & $0.45 \%$ \\
\hline
\end{tabular}

\begin{tabular}{|c|c|c|c|}
\hline \multirow[b]{2}{*}{ Waktu } & \multicolumn{3}{|c|}{ Suhu Air Masuk Chiller } \\
\hline & $\begin{array}{l}\text { Lab VI } \\
\text { (Ts4) }\end{array}$ & $\begin{array}{l}\text { Termometer } \\
\text { (Tt4) }\end{array}$ & $\begin{array}{c}\varepsilon_{t} 4 \text { Error } \\
\left.\frac{\Delta T}{T_{t} 4} x \mathbf{1 0 0} \%\right)\end{array}$ \\
\hline $12: 11: 58$ & 14.07 & 14.00 & 0.5 \\
\hline $12: 37: 00$ & 13.95 & 14.10 & 1.06 \\
\hline $12: 48: 05$ & 13.81 & 13.90 & 0.6 \\
\hline $13: 06: 49$ & 13.64 & 13.60 & 0.4 \\
\hline $13: 10: 53$ & 13.65 & 13.68 & 0.2 \\
\hline $13: 50: 40$ & 13.47 & 13.40 & 0.5 \\
\hline $14: 03: 16$ & 13.37 & 13.30 & 0.5 \\
\hline $14: 10: 06$ & 13.26 & 13.30 & 0.3 \\
\hline $14: 54: 03$ & 12.73 & 12.80 & 0.5 \\
\hline $15: 04: 03$ & 12.54 & 12.64 & 0.7 \\
\hline $15: 11: 43$ & 11.24 & 11.30 & 0.5 \\
\hline
\end{tabular}

\begin{tabular}{cccc}
$15: 50: 22$ & 10.87 & 10.80 & 0.6 \\
$16: 04: 30$ & 10.70 & 10.78 & 0.7 \\
$16: 10: 41$ & 10.50 & 10.54 & 0.3 \\
& $\% \mathcal{E}_{T}$ & & $0.52 \%$ \\
\hline
\end{tabular}

Berdasarkan tabel di atas dapat dilihat presentase kesalahan pembacaan dengan sensor RTD PT100 dengan Termometer yaitu memiliki rata-rata prosentase kesalahan $0.52 \%$ pada sensor RTD di pipa inlet, $0.57 \%$ pada pipa outlet chiller $1,0.41 \%$ pada pipa outlet chiller 2, dan $0.45 \%$ pada pipa outlet chiller 3. Berdasarkan hasil pengujian menunjukan bahwa sensor RTD PT100 cukup baik dan mendekati dengan nilai pada data sheet yaitu $\pm 0.15^{\circ} \mathrm{C}$

\section{Aplikasi Hasil Penelitian}

Modifikasi Panel kontrol sistem penyedia air dingin pada sistem ventilasi zona radiasi menegah dapat digunakan dengan baik di PRSG GAS BATAN, dengan memiliki efesiensi waktu yang lebih baik dalam menghidupkan chiller 01 . Chiller 02, dan chiller 03.

Menggunakan thermostat yang telah di setting dan terpasang pada pipa inlet, serta dapat memonitoring suhu air yang masuk pada pipa inlet dan suhu air yang keluar dari masing- masing chiller yaitu chiller 01, chiller 02, dan chiller 03 dan me-monitoring listrik yang ada pada pompa sirkulasi

Pada masing-masing chiller1, chiller 2 dan chiller3 guna mengetahui efektifitas pompa sirkulasi dalam mensirkulasikan air menuju chiller dan dari data hasil monitoring berupa besaran listrik pada pompa sirkulasi yang disimpan dalam database dapat digunakan untuk menganalisa jika terjadi fault atau gangguan pada pompa sirkulasi.

\section{KESIMPULAN DAN SARAN Kesimpulan}

1. Modifikasi panel kontrol sistem penyedia air dingin berhasil dirancang menggunakan selector switch dan thermostat yang terpasang pada pipa inlet dengan melakukan setting di suhu $11,5^{\circ} \mathrm{C}$ untuk mengontrol chiller 1 , chiller 2 dan chiller 3 dan berhasil menguji Ketiga chiller yang akan hidup jika suhu air yang masuk pada pipa inlet berada di atas suhu setting thermostat yaitu $13,5^{\circ} \mathrm{C}$, ketika suhu air yang masuk pada pipa inlet berada diantara 
suhu $11,5 \mathrm{C}<$ suhu $\mathrm{x}<13,5 \mathrm{C}$ maka secara otomatis thermostat akan menghidupkan 2 chiler, selanjutnya ketika suhu air yang masuk pada pipa inlet berada dibawah suhu setting thermostat yaitu $10^{\circ} \mathrm{C}$, maka secara otomatis thermostat hanya akan menghidupkan satu chiller

2. Sistem monitoring suhu air masuk pada pipa inlet, suhu air keluar dari chiller dan besaran listrik pada pompa sirkulasi menggunakan program Labview berhasil menampilkan kerja chiller secara real time dengan kondisi ON atau OFF, dan berhasil menampilkan data pengukuran dalam bentuk grafik dan nominal dengan memiliki prosentase kesalahan pembacaan pada RTD PT 100 di pipa inlet adalah $0.52 \%$, pipa outlet chiller 1 adalah $0.57 \%$, pipa outlet chiller 2 adalah $0.41 \%$, dan pipa outlet chiller 3 adalah $0.45 \%$, dan prosentase kesalahan pembacaan pada sensor current trafo yang ada di pompa sirkulasi chiller 1 adalah $1.24 \%$, pompa sirkulasi chiller 2 adalah $1.51 \%$, dan pompa sirkulasi chiller 3 adalah $1.27 \%$

\section{Saran}

Beberapa saran yang dapat disampaikan untuk meningkatkan kualitas dan kehandalan Modifikasi Panel Kontrol Sistem Penyedia Air Dingin pada Sistem Ventilasi Zona Radiasi Menengah agar lebih baik adalah:

1. Untuk pengembangan sebaiknya dapat menambahkan modul relay NI 9482 kontrol National Instrument sebagai pengontrol sistem otomatisasi pengoperasian chiller yang berbasis program Labview

2. Menambahkan sensor flow water dan sensor pressure untuk menampilkan kecepatan aliran air masuk pada pipa inlet dan besaran tekanan air masuk

3. Sebaiknya menambahkan modem wavecom agar dapat mengendalikan ataupun monitoring sistem melalui dashboard dari jarak jauh secara online

\section{DAFTAR PUSTAKA}

Arindya, Raditya. 2013. Penggunaan dan Pengaturan motor listrik. Yogyakarta: Graha Ilmu
Bernard, Wood. 1988, Penerapan Termodimamika edisi kedua , Jakarta : Erlangga

EGA. 2016 Komponen-Komponen pada Panel Listrik.http://egatek.com/ketahui-komponenkomponen-pada-panel-listrik/. Diakaes pada 23 desember 2016

Gunawan, Ricky.1988, Pengantar Teori Teknik Pendinginan (Refrijerasi). Jakarta : Direktorat jendral pendidikan tinggi

Harahap, S.A. 2015. Diktat Perawatan Sistem Mekanik Reaktor dan Sistem Terkait. Serpong: BATAN

Hasan, Syamsyuri Dkk. 2013. Sistem Refrigerasi dan Tata Udara Jilid 2. Jakarta: Direktorat Pembinaan Sekolah Menengah Kejuruan

Iwan Kurniawan,1998. Merawat dan Memperbaiki AC:Jakarta: Puspa Swara

Jerome,Jovitha,2010, Virtual Instrumentation Using LABVIEW,New Delhi: PSG College of Techonolgy

National Instrumen. 2011. NI PS-15 Power Supply User Manual. http:// www.ni.com/pdf/manuals/372911b.pdf.

Diakses 20 Januari 2016

National Instrumen. 2014. NI 9205 Operating Instructions and Specifications. http://www.ni.com/pdf/manuals/374188d.pdf. Diakses 1 Februari 2016

National Instrumen. 2016. Taking Temperature Measurements with RTDs: How-To-Guide. http://www.ni.com/tutorial/7115/en/. Diakses 27 April 2016

Russell E,Smith. 2011.Electricity for Refrigeration, Heating, and Air Conditioning. Del mar, USA: Cengage Learning

Setiawan, Anwar. 2014. Pengenalan Lab-View dan Pembuatan Plant Instrument. UNIKOM

Sumanto,Drs. 2004. Dasar-dasar mesin pendingin. Jogyakarta: Andi Offset

Sunarno. 2005. Mekanikal Elektrikal. Jogyakarta: Andi Offset

Widodo, Sapto. 2009. Sisitem kelistrikan Refrigerasi dan Tata Udara. Bandung: Yrama Widya

Yahya. 2010. Simulasi kegagalan Sistem Ventilasi RSG-GAS dan Penanganannya. Yogyakarta: Seminar Nasional IV ISSN 19780176 
York, 2015. Model YLAA Engineering,Milwake: York International Corporation

York,2000. Model Engineering Guide, Penyslvania : York International Corporation ZIEHL,2015. Pt100 Temperature Sensors Type TF 101, ZIEHL Industrie-Elektronik 